\title{
SUMBANGAN PEMIKIRAN HAK ASASI MANUSIA TERHADAP PEMBAHARUAN KITAB UNDANG-UNDANG HUKUM ACARA PIDANA (KUHAP)
}

\author{
Ari Wibowo \\ Prodi Ilmu Hukum Universitas Islam Indonesia, Yogyakarta \\ Email: ari_bowo1986@yahoo.com
}

\begin{abstract}
The idea of renewal of the Criminal Procedure Code can not be separated from the conceptual contribution of Human Rights (HAM). This contribution has been explicitly included in the preamble of the draft of Criminal Procedure Code. Although the current Criminal Procedure Code already provides protection to the rights of the suspect or the accused, but the implementation is still not optimal. Therefore, in the draft of Criminal Procedure Code there is a new institution called the Judicial Commissioner (Rechter-Commissaris) to replace the function of Pretrial institutions. The Judicial Commissioner has far wider powers of Pretrial institution, so that the protection of the rights of suspects or defendants in any stage of the judicial process will be more secure fulfillment. The development of human rights concept also contributed to the idea to regulate the rights of victims in the renewal of the Criminal Procedure Code. Protection of the rights of victims in the current Criminal Procedure Code is limited to the rights to the incorporation of lawsuits for damages to the criminal case. Because it has not adequately regulated in the current Criminal Procedure Code, the draft of Criminal Procedure Code regulates the rights of victims, both associated with involvement in all stages of judicial proceedings and the right to sue for damages.
\end{abstract}

Key words : contribution of human rights concept, renewal of criminal procedure code

\section{Pendahuluan}

Menurut Hobbes, manusia pada dasarnya memiliki watak agresif, yaitu naluri untuk menyerang, menguasai harta orang lain atau memiliki ambisi untuk berkuasa. Karena watak itulah sehingga manusia bisa menjadi serigala bagi orang lain (homo homini lupus) (Ahmad Suhelmi, 2001:247). Bertolak dari pandangan Hobbes tersebut, maka keberadaan kejahatan merupakan suatu keniscayaan dalam kehidupan bermasyarakat. Kejahatan tidak mungkin dihilangkan, namun hanya dapat dikurangi kuantitas dan kualitasnya. Pernyataan tersebut secara empiris juga dapat dibuktikan bahwa sejak manusia dilahirkan hingga saat ini kejahatan terus ada bahkan semakin kompleks.

Karena adanya kecenderungan dari setiap orang untuk melakukan kejahatan, maka dibutuhkan institusi yang dapat mengatur kehidupan bermasyarakat agar hak-hak setiap manusia dapat terlindungi dari kejahatan orang lain. Atas dasar inilah John Locke mengemukakan teori yang dikenal sebagai social contract theory (teori kontrak sosial). Menurut teori ini, Negara dibangun atas dasar kontrak sosial antara pemerintah sebagai pemegang kekuasaan dengan rakyat sebagai pemegang kedaulatan. Pemerintah diberikan kekuasaan untuk menyelenggarakan ketertiban dan menciptakan suasana dimana rakyat dapat menikmati hak-hak alamnya (natural right) dengan aman. Di lain pihak rakyat akan mematuhi pemerintah apabila hak-hak tersebut terjamin (Mariam Budiardjo, 2008: 111).

Atas dasar kontrak sosial tersebut, pemerintah diberikan kekuasaan untuk menentukan kebijakan-kebijakan guna menciptakan ketertiban masyarakat, salah satunya melalui kebijakan hukum pidana (penal policy) (Mokhammad Najih, 2008: 29). Menurut A. Mulder, kebijakan hukum pidana merupakan garis kebijakan untuk menentukan seberapa jauh ketentuan-ketentuan pidana yang berlaku perlu diubah atau diperbaharui, apa yang dapat diperbuat untuk mencegah 
terjadinya tindak pidana, dan cara bagaimana penyidikan, penuntutan, peradilan dan pelaksanaan pidana harus dilaksanakan (Barda Nawawi Arief, 2003: 26). Ruang lingkup dari kebijakan hukum pidana dapat meliputi kebijakan formulatif, aplikatif, dan eksekutif (Arief Amrullah, 2007: 21). Dengan demikian, kebijakan hukum pidana tidak hanya berhenti pada pembuatan undang-undang, namun lebih dari itu harus ditegakan.

Pada tahapan formulatif, kebijakan hukum pidana menghasilkan undang-undang hukum pidana yang meliputi tiga bentuk, yaitu hukum pidana materiel, hukum pidana formil (hukum acara pidana) dan hukum pidana eksekutoriel. Hukum pidana materiel adalah norma-norma yang berisi perbuatan-perbuatan yang tidak boleh dilakukan, dilarang, dengan disertai ancaman atau sanksi yang berupa pidana tertentu bagi yang melanggarnya. Sedangkan hukum pidana formil adalah norma-norma yang mengatur kapan dan dalam hal apa kepada mereka yang melanggar larangan-larangan itu dapat dikenakan atau dijatuhi pidana sebagaimana yang telah diancamkan. Hukum pidana eksekutoriel sendiri merupakan norma-norma dengan cara bagaimana pengenaan pidana itu dapat dilaksanakan apabila ada orang yang diputus telah melanggar larangan tersebut (Moeljatno, 2008: 1).

Saat ini, undang-undang induk hukum pidana materiel di Indonesia adalah Kitab Undang-Undang Hukum Pidana (KUHP), sedangkan undang-undang induk hukum pidana formilnya adalah Kitab Undang-Undang Hukum Acara Pidana (KUHAP). Karena usianya sudah sangat tua, maka dipandang perlu untuk dilakukan pembaharuan terhadap kedua undang-undang kodifikasi tersebut. Sebenarnya ide untuk melakukan pembaharuan sudah lama ada, namun hingga saat ini baik Rancangan KUHP maupun KUHAP belum juga disahkan oleh Dewan Perwakilan Rakyat (DPR).

Di samping KUHP, pembaharuan terhadap KUHAP sudah merupakan kebutuhan mendesak. KUHAP sendiri diatur melalui UU No. 8 Tahun 1981 tentang KUHAP yang berlaku mulai tanggal 31 Desember 1981. KUHAP merupakan hukum acara pidana yang menggantikan Herziene Inlandsch Reglement (HIR) warisan kolonial Belanda yang ketika itu dianggap tidak sesuai lagi dengan karakteristik negara merdeka. Berbeda dengan HIR, KUHAP memperlihatkan ciri yang humanis, tidak lagi menggunakan cara-cara kekerasan (violence) atau penyiksaan (torture) oleh aparat penegak hukum (Yesmil Anwar dan Adang, 2008: 45). Seiring dengan berjalannya waktu, kemudian muncul ide untuk melakukan pembaharuan terhadap KUHAP dan saat ini telah terbentuk Rancangan KUHAP. Salah satu faktor yang mempengaruhi ide pembaharuan KUHAP adalah perkembangan pemikiran Hak Asasi Manusia (HAM). Oleh karena itu, artikel ini hendak mengkaji bagaimana sumbangan pemikiran HAM terhadap pembaharuan KUHAP.

\section{Konsep Pembaharuan Hukum Pidana}

Pembaharuan hukum pidana dapat dimaknai sebagai perubahan terhadap hukum pidana. Pembaharuan hukum pidana dilakukan secara sistemik, yaitu dengan pendekatan yang integral dan menyeluruh. Namun perlu menjadi catatan, bahwa pendekatan sistemik tidak mengharuskan perubahan hukum pidana secara total, namun tetap mempertahankan yang masih dianggap baik, mengganti yang dianggap tidak sesuai dan menambah yang dianggap kurang (Teguh Prasetyo, 2010: 30). Pembaharuan hukum pidana hendaknya tidak hanya dilakukan oleh orang yang duduk di pemerintahan, namun dibutuhkan juga peran dari akademisi. Para pakar hukum pidana harus merasa dirinya sebagai bagian dari sistem hukum pidana, tidak terbatas sebagai pengamat, namun sebagai kontributor dalam pembuatan dan penerapan hukum pidana (Markus Dirk Dubber: 1999).

Objek pembaharuan hukum pidana meliputi hukum pidana dalam arti makro dan mikro. Pembaharuan hukum pidana secara makro meliputi pembaharuan pada struktur atau lembagalembaga sistem peradilan pidana, substansinya yang menyangkut harmonisasi atau sinkronisasi hukum pidana, serta pembaharuan aspek budaya masyarakat dan nilai-nilai filosofis kehidupan. 
Sedangkan secara mikro, pembaharuan hukum pidana menyangkut tiga masalah pokok dalam hukum pidana, yaitu perbuatan pidana, pertanggungjawaban pidana, dan pidana (Teguh Prasetyo, 2010: 31).

Dari penjelasan tersebut dapat disimpulkan bahwa pembaharuan hukum pidana tidak sekedar melakukan pembaharuan pada hukum pidana materiel, namun juga secara makro dilakukan terhadap ruang lingkup yang lebih luas termasuk hukum pidana formil dan eksekutoriel, bahkan lebih dari itu hingga menyentuh kebijakan kriminal dan kebijakan sosial.

Menurut Barda Nawawi Arief, makna dan hakekat pembaharuan hukum pidana meliputi: (Barda Nawawi Arief, 2008: 26)

1. Dilihat dari sudut pendekatan kebijakan, yaitu:

a. Sebagai bagian dari kebijakan sosial (social policy), pembaharuan hukum pidana pada hakekatnya merupakan bagian dari upaya untuk mengatasi masalah-masalah sosial (termasuk masalah kemanusiaan) dalam rangka mencapai tujuan nasional.

b. Sebagai bagian dari kebijakan (criminal policy), pembaharuan hukum pidana pada hakekatnya merupakan bagian dari upaya perlindungan masyarakat (social defence), khususnya penanggulangan kejahatan.

c. Sebagai bagian dari kebijakan penegakan hukum (law enforcement policy), pembaharuan hukum pidana pada hakekatnya merupakan bagian dari upaya memperbaharui substansi hukum (legal substance) dalam rangka lebih mengefektifkan penegakan hukum.

2. Dilihat dari sudut pendekatan nilai, pembaharuan hukum pidana pada hakekatnya merupakan upaya melakukan peninjauan dan pendekatan kembali (re-orientasi dan re-evaluasi) nilai-nilai sosiopolitik, sosiofilosofis dan sosiokultural yang melandasi dan memberi isi terhadap muatan normatif dan subtantif hukum pidana yang dicitacitakan. Bukan merupakan pembaharuan hukum pidana apabila orientasi nilai yang dicita-citakan sama saja dengan hukum pidana yang telah ada sebelumnya.

Dari penjelasan di atas, pembaharuan hukum pidana bukan hanya melakukan pembaharuan kebijakan dalam rangka mencapai kebijakan sosial, kebijakan kriminal, dan kebijakan penegakan hukum. Namun lebih dari itu, pembaharuan hukum pidana harus berorientasi pada nilai-nilai yang dicita-citakan. Dengan berorientasi pada nilai, maka pembaharuan hukum pidana bersifat jangka panjang, tidak pragmatis. Pembaharuan hukum pidana yang tanpa berorientasi pada nilai tidak akan menghasilkan produk yang bersifat jangka panjang. Problem inilah yang biasanya terjadi di Indonesia, sehingga sering terjadi penggantian atau perubahan undang-undang.

\section{Sumbangan Pemikiran HAM terhadap Pembaharuan KUHAP}

Menurut Jan Materson, HAM merupakan hak-hak yang melekat pada manusia yang tanpanya manusia mustahil dapat hidup sebagai manusia. Menurut Burhanuddin Lopa, pada kalimat "mustahil dapat hidup sebagai manusia" hendaklah diartikan "mustahil dapat hidup sebagai manusia yang bertanggung jawab". Alasan ditambahkan kata "tanggung jawab" tersebut ialah disamping manusia memiliki hak, juga memiliki tanggung jawab atas segala yang dilakukannya. Sementara menurut John Lock, HAM adalah hak-hak yang diberikan langsung oleh Tuhan Yang Maha Pencipta (hak-hak yang bersifat kodrati) (Burhanuddin Lopa, 1996: 1-2).

Konsepsi HAM sendiri memiliki dua dimensi (dimensi ganda), yaitu:

1. Dimensi universalitas, yakni substansi HAM itu pada hakekatnya bersifat umum dan tidak terikat oleh waktu dan tempat. HAM akan selalu dibutuhkan oleh siapa saja dan dalam aspek kebudayaan dimana pun itu berada, entah itu dalam kebudayaan barat maupun timur. Dimensi HAM seperti ini pada hakekatnya akan selalu dibutuhkan 
dan menjadi sarana bagi individu untuk mengekspresikan secara bebas dalam ikatan kehidupan kemasyarakatan. Dengan kata lain hak asasi itu ada karena yang memiliki hak-hak itu adalah manusia sebagai manusia.

2. Dimensi kontekstualitas, yakni menyangkut penerapan HAM bila ditinjau dari tempat berlakunya HAM tersebut. Maksudnya adalah ide-ide HAM dapat diterapkan secara efektif, sepanjang "tempat" ide-ide HAM itu memberikan suasana kondusif untuk itu. Dengan kata lain ide-ide HAM akan dapat dipergunakan scara efektif dan menjadi landasan etik dalam pergaulan manusia, jika struktur kehidupan masyarakat entah itu di barat ataupun di timur sudah tidak memberikan tempat bagi terjaminnya hak individu yang ada di dalamnya (Restu Cipto Handoyo, 2003: 271).

Dua dimensi inilah yang memberikan pengaruh terhadap pelaksanaan ide-ide HAM di dalam komunitas kehidupan masyarakat, bangsa dan negara, tidak terkecuali Indonesia. Oleh sebab itu dengan adanya dua dimensi ini, maka perdebatan mengenai pelaksanaan ide-ide HAM yang diletakkan dalam konteks budaya, suku, ras maupun agama sudah tidak mempunyai tempat lagi atau tidak relevan dengan wacana publik masyarakt modern.

Pemikiran HAM banyak memberikan pengaruh terhadap warna hukum di Indonesia. Amandemen kedua UUD 1945 telah memberikan perubahan terhadap pengaturan HAM di Indonesia. Jika sebelum amandemen kedua pengaturan HAM dalam UUD 1945 diatur secara terpisah pisah dalam beberapa pasal, namun pasca amandemen kedua, UUD 1945 telah mengatur HAM secara lebih sistematis dalam satu bab, yaitu di dalam bab XA tentang Hak Asasi Manusia yang terdiri dari pasal 28A sampai dengan pasal 28J. Disamping itu, perhatian Indonesia terhadap perlindungan HAM ditunjukkan dengan pengaturan HAM secara khusus melalui Undang-Undang Nomor 39 tahun 1999 tentang Hak Asasi Manusia.

Dalam lingkup Internasional, terdapat The International Bill of Human Rights yang merupakan istilah yang digunakan untuk acuan kolektif terhadap tiga instrumen pokok HAM dan protokol opsinya, yaitu: (C. De Rover, 2000: 55)

1. Pernyataan sejagat tentang HAM atau The Universal Declaration of Human Rights (UDHR) yang ditetapkan oleh PBB pada tanggal 10 Desember 1948.

2. Konvenan International tentang Hak-hak Sipil dan Politik atau International Convenant on Civil and Political Right (ICCPR).

3. Konvenan Internasional tentang Hak-Hak Ekonomi, Sosial dan Budaya atau International Convenant on Economic, Social, and Cultural Right (ICESCR).

4. Protokol Opsi Pertama pada ICCPR.

Pemikiran HAM juga memberikan sumbangan terhadap ide pembaharuan KUHAP. Dalam konsideran Rancangan KUHAP tahun 2009 disebutkan bahwa "pembaruan hukum acara pidana juga dimaksudkan untuk lebih memberikan kepastian hukum, penegakan hukum, ketertiban hukum, keadilan masyarakat, dan perlindungan hukum serta hak asasi manusia, baik bagi tersangka, terdakwa, saksi, maupun korban, demi terselenggaranya negara hukum." Dari konsideran tersebut terlihat bahwa salah satu nilai yang hendak dibangun dalam pembaharuan KUHAP adalah HAM.

Masuknya pemikiran-pemikiran HAM ke dalam pembaharuan KUHAP tidak dapat dilepaskan dari pengaruh konvensi-konvensi internasional tentang HAM yang telah diratifikasi oleh Indonesia. Hal ini telah dinyatakan secara eksplisit dalam konsideran Rancangan KUHAP, yaitu "berhubung beberapa konvensi internasional yang berkaitan langsung dengan hukum acara pidana telah diratifikasi, maka hukum acara pidana perlu disesuaikan dengan materi konvensi tersebut." 


\section{Perlindungan Hak-Hak Tersangka atau Terdakwa}

Ide perlindungan terhadap hak-hak tersangka atau terdakwa merupakan sumbangan dari pemikiran HAM yang terdapat dalam The International Bill of Human Rights, terutama UDHR dan ICCPR. UDHR banyak memberikan kontribusi yang sangat signifikan terhadap konstitusi dan hukum nasional negara-negara anggota, tidak terkecuali Indonesia (C. De Rover, 2000: 56). Sedangkan pembaharuan KUHAP lebih banyak dipengaruhi oleh ICCPR yang telah diratifikasi oleh Indonesia dengan Undang-Undang No. 12 Tahun 2005.

ICCPR banyak memberikan sumbangan terhadap pembaharuan KUHAP terutama terkait dengan perlindungan hak tersangka atau terdakwa. Asas pokok yang menjadi payung perlindungan terhadap tersangka atau terdakwa adalah asas "praduga tidak bersalah." Asas praduga tidak bersalah merupakan asas yang menghendaki agar setiap orang yang terlibat dalam perkara pidana harus dianggap belum bersalah sebelum ada putusan pengadilan yang menyatakan kesalahan itu. Asas ini harus dipatuhi oleh penegak hukum baik dalam proses penyidikan, penuntutan maupun pemeriksaan di pengadilan (Rusli Muhammad, 2007: 17).

Pengaturan mengenai asas ini terdapat dalam Article 11 (1) UDHR yang menyatakan: "Everyone charged with a penal offence has the right to be presumed innocent until proved guilty according to law in a public trial at which he has had all the guarantees necessary for his defense." Senada dengan Article 11 UDHR, dalam Article 14 (2) ICCPR juga dinyatakan: "Everyone charged with a criminal offence shall have the right to be presumed innocent until proved guilty according to law."

Kedua Article tersebut memberikan hak kepada setiap orang untuk dianggap tidak bersalah sampai dibuktikan kesalahannya secara sah dalam suatu sidang pengadilan. Asas praduga tidak bersalah mengandung konsekuensi bahwa untuk dianggap bersalah oleh pengadilan, maka seseorang harus dipenuhi hak-haknya sebagai berikut:

1. hak atas peradilan yang bebas, jujur dan tidak memihak (independent judiciary and fair trial); dan

2. hak atas bantuan dari profesi hukum yang bebas (independent legal profession).

Dalam rangka menjamin agar proses peradilan tidak dilaksanakan secara sewenang-wenang, maka jalannya pemeriksaan harus terbuka untuk umum. Asas publisitas atau keterbukaan merupakan asas yang sangat pokok untuk menjamin berjalannya proses peradilan yang independen, jujur dan tidak memihak (Barda Nawawi Arief, 2008: 70-71).

Sebelum masuk ke dalam tahap pemeriksaan pengadilan, apabila seseorang ditangkap, maka ia berhak untuk segera diberitahukan mengenai tuduhan yang dikenakan kepadanya. Aticle 9 (2) ICCPR menyatakan bahwa "Anyone who is arrested shall be informed, at the time of arrest, of the reasons for his arrest and shall be promptly informed of any charges against him." Persoalan yang muncul terkait dengan pasal ini antara lain: Apakah informasi yang diberikan harus merupakan hal-hal yang umum atau yang khusus? dan apakah informasi harus disampaikan dalam bentuk tertentu? (Haji N.A. Noor Muhammad, dalam Ifdhal Kasim, ed., 2001: 184).

Untuk menjawab persoalan-persoalan tersebut, Komisi Eropa mengenai HAM memberikan petunjuk bahwa orang yang ditangkap atau ditahan cukup diberitahukan tuduhan yang bersifat umum saja, sedangkan pada saat diperiksa di pengadilan, informasi mengenai tuduhan terhadapnya diberitahukan secara resmi. Informasi mengenai tuduhan tersebut tidak harus tertulis dan jika diberikan secara lisan tidak perlu berbentuk khusus. Apabila orang yang ditangkap telah membaca surat perintah penangkapan, maka alasan-alasan penangkapannya harus diberitahukan secara cepat-cepat (Haji N.A. Noor Muhammad, dalam Ifdhal Kasim, ed., 2001: 184).

Hak selanjutnya adalah orang yang ditangkap atau ditahan berdasarkan tuduhan pidana wajib segera dihadapkan ke depan pengadilan atau pejabat lain yang diberi kewenangan oleh hukum untuk menjalankan kekuasaan peradilan, dan berhak untuk diadili dalam jangka waktu 
yang wajar, atau dibebaskan. Hak ini sebagaimana yang dijamin dalam Article 9 (3) ICCPR. Istilah "segera" di sini menunjukkan bahwa negara-negara harus memberikan batas waktu penahanan. Persoalannya setiap negara memiliki aturan yang berbeda mengenai batas waktu penahanan. Seringkali negara memberikan batas penahanan yang sangat panjang belum lagi masih ada perpanjangan dalam setiap habis masa penahanan. Inilah yang sering mengakibatkan pelanggaran terhadap ICCPR (Ifdhal Kasim, 2001: 185-186).

Dalam Article 9 (3) ICCPR juga disebutkan bahwa setiap orang berhak untuk diadili dalam jangka waktu yang wajar, atau dibebaskan. Maksud dari "waktu yang wajar" di sini berhubungan dengan Article 14 (3c) ICCPR yaitu hak untuk diadili tanpa penundaan yang tidak semestinya. Untuk menilai sifat penundanaan yang layak atau harus tidak dipandang in abstracto, melainkan dari sudut keadaan-keadaan tertentu seperi kompleksitas kasusnya (Ifdhal Kasim, 2001: 192).

Setiap orang yang diperiksa berhak mendapatkan bantuan hukum sejak proses penyidikan hingga putusan pengadilan yang berkekuatan hukum tetap. Pemerintah menyediakan bantuan hukum kepada mereka yang tidak mampu untuk membiayainya. Untuk keadaan tertentu, tersangka atau terdakwa berhak mendapatkan bantuan lain terkait perlindungan haknya selama proses peradilan, misalnya untuk mendapatkan bimbingan rohani dan psikologi apabila diperlukan (Rhona K.M Smith, dkk., 2008: 260-261).

Dalam rangka lebih memberikan jaminan terhadap hak tersangka atau terdakwa dalam setiap proses peradilan, maka pada Rancangan KUHAP dilakukan pembaharuan dengan merubah Praperadilan menjamin Hakim Komisaris. Hakim Komisaris akan menggantikan peranan Ketua Pengadilan Negeri (PN) atau Hakim Praperadilan. Dalam pasal 1 angka 10 KUHAP menyatakan bahwa Praperadilan hanya berwenang untuk memeriksa dan memutus tentang sah atau tidaknya suatu penangkapan dan/atau penahanan; sah atau tidaknya penghentian penyidikan atau penghentian penuntutan; dan permintaan ganti kerugian atau rehabilitasi oleh tersangka atau keluarganya atau pihak lain atas kuasanya yang perkaranya tidak diajukan ke pengadilan.

Meskipun memiliki wewenang yang terbatas, namun keberadaan Praperadilan dalam KUHAP merupakan ikon pembaruan terhadap HIR. HIR tidak mengatur bagaimana seseorang tersangka seharusnya dilindungi dari proses pemeriksaan penyidik ketika ditetapkan sebagai tersangka. Menurut HIR, penyidik harus dapat memperoleh pengakuan dari tersangka mengenai peristiwa yang melibatkan dirinya karena pengakuan tersangka merupakan salah satu alat bukti utama. Akibatnya, untuk memperoleh pengakuan tersangka, maka sering terjadi perlakuan yang sewenang-wenang dan penyalahgunaan wewenang oleh penyidik. Selain itu, HIR juga tidak memberikan perlindungan hukum yang memadai terhadap seorang tersangka tentang pemberian bantuan hukum yang hanya ditawarkan oleh penuntut umum terhadap seorang tersangka yang diancam dengan hukuman mati (Romli Atmasasmita, 2010).

Keberadaan Praperadilan dalam perkembangannya kemudian memunculkan berbagai hambatan, sehingga maksud dan tujuan pemberlakuan Praperadilan tidak tercapai secara baik dan benar. Hal ini mengakibatkan hak-hak tersangka untuk memperoleh perlindungan hukum tidak terpenuhi dengan baik. Hambatan lain yang mencolok adalah bolak-baliknya perkara pidana dari penyidik Polri ke Jaksa sehingga hak tersangka untuk memperoleh kepastian hukum terabaikan, bahkan sering terjadi bolak-baliknya perkara pidana dilatarbelakangi oleh kepentingan pribadi atau kelompok atau politik (Romli Atmasasmita, 2010).

Beberapa kelemahan dalam pelaksanaan KUHAP di atas memunculkan ide perubahan terhadap KUHAP, salah satunya melalui pembentukan Hakim Komisaris untuk menggantikan Praperadilan. Dalam pasal 111 ayat (1) Rancangan KUHAP, Hakim Komisaris diberikan wewenang yang jauh lebih luas dari Praperadilan, yaitu menetapkan atau memutuskan tentang:

1. sah atau tidaknya penangkapan, penahanan, penggeledahan, penyitaan, atau penyadapan; 
2. pembatalan atau penangguhan penahanan;

3. bahwa keterangan yang dibuat oleh tersangka atau terdakwa dengan melanggar hak untuk tidak memberatkan diri sendiri;

4. alat bukti atau pernyataan yang diperoleh secara tidak sah tidak dapat dijadikan alat bukti;

5. ganti kerugian dan/atau rehabilitasi untuk seseorang yang ditangkap atau ditahan secara tidak sah atau ganti kerugian untuk setiap hak milik yang disita secara tidak sah;

6. tersangka atau terdakwa berhak untuk atau diharuskan untuk didampingi oleh pengacara;

7. bahwa Penyidikan atau Penuntutan telah dilakukan untuk tujuan yang tidak sah;

8. penghentian Penyidikan atau penghentian Penuntutan yang tidak berdasarkan asas oportunitas;

9. layak atau tidaknya suatu perkara untuk dilakukan Penuntutan ke pengadilan; dan

10. pelanggaran terhadap hak tersangka apapun yang lain yang terjadi selama tahap Penyidikan.

Keberadaan Hakim Komisaris dengan wewenang sebagaimana di sebutkan di atas lebih menunjukan jaminan perlindungan terhadap hak-hak tersangka dan terdakwa dibanding dengan Praperadilan. Pelanggaran HAM terhadap tersangka atau terdakwa tindak pidana dapat terjadi pada tataran norma (undang-undang), namun lebih nampak jelas dalam tataran pemeriksaan dalam semua tahapan sistem peradilan pidana. Dalam tahapan ini aparat penegak hukum berpotensi menggunakan kekuasaannya baik dalam bentuk ancaman fisik mapun psikis terhadap pelaku tindak pidana mulai pemanggilan, penentuan sebagai tersangka atau terdakwa, pemeriksaan yang berlarut-larut, penahanan yang tidak sah bahkan sampai pada rekayasa perkara. Rekayasa perkara merupakan pelanggaran HAM yang sangat kejam dalam proses penegakan hukum, yaitu dengan sengaja menciptakan seseorang sebagai pelaku tindak pidana. Meminjam istilah Richard Quinney bahwa penegak hukum membangun rangkaian (proses) konstruksi kejahatan dalam proses peradilan (Anthon F. Susanto, dalam Muladi, ed., 2007: 113).

Keberadaan Hakim Komisaris tersebut mengindikasikan bahwa model beracara dalam Rancangan KUHAP lebih condong kepada model Due Process of Law (DPL). Sebagaimana ciri model DPL, keberadaan Hakim Komisaris menitikberatkan pada perlindungan hak-hak tersangka dan terdakwa dalam proses peradilan (Eddy O.S Hiariej: 2010). Secara umum, DPL menekankan pada peran hukum dan aturan-aturan prosedural yang harus ditataati dalam setiap proses hukum. Prinsip pokok dari DPL antara lain: perlindungan tersangka atau terdakwa, persamaan para pihak dan presumption of innocence (Arif Setiawan, 2010: 10-11).

\section{Perlindungan Terhadap Hak-Hak Korban}

Di samping perlindungan terhadap tersangka atau terdakwa, perkembangan pesat mengenai pemikiran HAM telah membawa pemikiran akan pentingnya perlindungan terhadap korban kejahatan. Dalam KUHAP, perlindungan terhadap korban masih sangat terbatas. Perlindungan korban dalam KUHAP hanya terdapat pada pasal 98 ayat (1) yang berbunyi:

Jika suatu perbuatan yang menjadi dasar dakwaan di dalam suatu pemeriksaan perkara pidana oleh pengadilan negeri menimbulkan kerugian bagi orang lain, maka hakim ketua sidang atas permintaan orang itu dapat menetapkan untuk menggabungkan perkara gugatan ganti kerugian kepada perkara pidana itu.

Dalam penjelasan pasal tersebut, orang lain di sini termasuk korban. Sehingga apabila korban merasa dirugikan terhadap seuatu kejahatan, maka ia dapat mengajukan gugatan ganti kerugian dengan menggabungkan dengan perkara pidana yang bersangkutan (Muhadar, dkk., 
2009: 110). Ganti kerugian di sini bukan merupakan sanksi pidana, namun bersifat keperdataan karena dalam KUHP tidak dikenal sanksi pidana ganti kerugian, kecuali hanya sebagai syarat untuk seseorang tidak menjalani pidana bersyarat (Barda Nawawi Arief, 2007: 62).

Atas pengaruh perkembangan pemikiran HAM, maka dilakukan pembaharuan pada KUHAP yang menitikberatkan pada offender-victim oriented (perindungan pelaku dan korban). Perhatian terhadap korban merupakan suatu keharusan atas dasar belas kasihan dan penghormatan terhadap martabatnya (compassion and respect for their dignity). Pada tahun 1985, PBB melalui Declaration of Basic Principle of Justice for Victims of Crime and Abuse of Power, memberikan perhatian yang lebih kepada akses korban untuk memperoleh keadilan, hak atas kompensasi, restitusi dan bantuan-bantuan lainnya yang harus diatur dalam UU nasional. Bahkan kompensasi tersebut juga berlaku terhadap keluarganya, khususnya yang hidupnya tergantung pada korban yang mati atau cacat, termasuk di sini korban penyalahgunaan kekuasaan (Muladi, dalam Muladi, ed., 2007: 106).

Dalam melakukan pengaturan terhadap perlindungan korban, aspek penting yang harus diperhatikan adalah esensi kerugian yang diderita oleh korban. Kerugian yang diderita korban dalam kejahatan bukan hanya bersifat materiel, namun lebih dari itu korban dapat menderita kerugian psikologis, seperti trauma kehilangan kepercayaan terhadap masyarakat dan ketertiban umum. Simtom dari sindrom tersebut dapat berupa kegelisahan, rasa curiga, sinisme, depresi, dan berbagai perilaku lainnya (Muladi dan Barda Nawawi, 2007: 84).

Selanjutnya, pengaturan terhadap perlindungan korban dapat menggunakan model hakhak prosedural (The Procedural Rights Model) dan model pelayanan (The Services Model). Model hak-hak prosedural memberikan kemungkinan kepada korban untuk dilibatkan dalam setiap tahapan proses peradilan. Dalam model ini, korban dapat diberikan hak untuk melakukan penuntutan pidana atau membantu kejaksaan untuk dihadirkan dalam setiap tingkat peradilan yang kepentingannya terkait, termasuk hak untuk mengadakan perdamaian. Sedangkan model pelayanan menekankan pada pemberian kompensasi sebagai sanksi pidana yang bersifat restitutif dan dampak-dampak pernyataan korban sebelum pidana dijatuhkan (Muladi dan Barda Nawawi, 2007: 85).

Menutut Stephen Schafer, terdapat lima sistem pemberian restitusi dan kompensasi terhadap korban kejahatan, yaitu: (Barda Nawawi Arief, 1998: 59-61)

1. Ganti kerugian bersifat keperdataan yang diberikan melalui proses perdata. Sistem ini memisahkan tuntutan ganti kerugian korban dengan proses pidana.

2. Kompensasi bersifat keperdataan yang diberikan melalui proses pidana.

3. Restitusi bersifat keperdataan dan bercampur dengan sifat pidana yang diberikan melalui proses pidana. Salah satu bentuk restitusi ini misalnya denda kompensasi (compensatory fine). Denda ini merupakan kewajiban yang dikenakan kepada terpidana sebagai suatu bentuk pemberian ganti kerugian kepada korban disamping pidana lain yang seharusnya dikenakan.

4. Kompensasi bersifat keperdataan yang diberikan melalui proses pidana dan disokong oleh negara. Kompensasi ini meskipun diberikan melalui proses pidana, namun tetap merupakan lembaga keperdataan murni tetapi negara yang menanggung ganti kerugian yang dibebankan kepada pelaku. Sistem ini merupakan pengakuan negara yang telah gagal melindungi warga negaranya dari terjadinya kejahatan.

5. Kompensasi bersifat netral yang diberikan melalui prosedur khusus. Sistem ini diterapkan dalam hal korban memerlukan ganti kerugian namun pelaku tidak mampu membayar ganti kerugian tersebut. Pemeriksaan tidak dilakukan melalaui pengadilan perdata dan pidana, melainkan prosedur khusus dan independen yang menuntut campur tangan negara atas permintaan korban. 
Pemikiran-pemikiran HAM terhadap hak-hak korban telah memberikan sumbangan terhadap pembaharuan KUHAP. Dalam Rancangan KUHAP diatur hak-hak korban, baik melalui pelibatannya dalam proses peradilan maupun pemberian ganti kerugian kepada korban. Hak-hak korban yang terkait proses peradilan misalnya hak mengajukan laporan atau pengaduan kepada Penyidik baik secara lisan maupun secara tertulis (Pasal 12); hak atas pemberitahuan penghentian penyidikan (Pasal 14); dan hak memperoleh perlindungan hukum karena mengajukan laporan laporan atau pengaduan kepada Penyidik, serta perlindungan hukum dalam setiap proses Penuntutan dan proses pemeriksaan di sidang pengadilan (Pasal 40).

Sedaangkan terkait ganti kerugian, pada bagian ketiga Rancangan KUHAP diatur mengenai Putusan Pengadilan Tentang Ganti Kerugian Terhadap Korban. Pasal 135 ayat (1) dan (2) berbunyi:

(1) apabila terdakwa dijatuhi pidana dan terdapat korban yang menderita kerugian materiel akibat tindak pidana yang dilakukan oleh terdakwa, Hakim mengharuskan terpidana membayar ganti kerugian kepada korban yang besarnya ditentukan dalam putusannya.

(2) Apabila terpidana tidak membayar ganti kerugian sebagaimana dimaksud pada ayat (1), harta benda terpidana disita dan dilelang untuk membayar ganti kerugian kepada korban.

\section{Kesimpulan}

Tidak dapat dipungkiri bahwa ide pembaharuan KUHAP tidak terlepas dari sumbangan pemikiran Hak Asasi Manusia (HAM). Sumbangan ini secara eksplisit telah dicantumkan dalam konsideran Rancangan KUHAP tahun 2009. Meskipun KUHAP sudah memberikan perlindungan terhadap hak-hak tersangka atau terdakwa, namun dalam implementasinya masih belum optimal. Oleh karena itu, dalam Rancangan KUHAP terdapat lembaga baru yang bernama Hakim Komisaris untuk menggantikan fungsi lembaga Praperadilan. Hakim Komisaris memiliki wewenang yang jauh lebih luas dari Praperadilan. Melalui wewenang yang lebih luas tersebut, hak-hak tersangka atau terdakwa dalam setiap tahapan proses peradilan akan lebih terjamin pemenuhannya.

Di samping hak-hak tersangka atau terdakwa, perkembangan pemikiran HAM memberikan sumbangan terhadap ide untuk mengatur hak-hak korban dalam pembaharuan KUHAP. KUHAP masih bersifat offender oriented, sehingga belum memberikan perlindungan hak-hak korban yang memadai. Hak korban dalam KUHAP masih terbatas pada hak korban atas penggabungan perkara gugatan ganti kerugian kepada perkara pidana. Karena belum diatur secara memadai dalam KUHAP, maka Rancangan KUHAP mengatur mengenai hak-hak korban, baik terkait dengan pelibatannya dalam setiap tahapan prosedur peradilan maupun hak untuk menuntut ganti kerugian. Pengaturan hak-hak korban dalam Rancangan KUHAP mencerminkan penekanan terhadap offender-victim oriented.

\section{Daftar Pustaka}

Ahmad Suhelmi. (2001). Pemikiran Politik Barat: Kajian Sejarah Perkembangan Pemikiran Negara, Masyarakat dan Kekuasaan. Jakarta: Penerbit Gramedia Pustaka Utama.

Arief Amrullah. (2007). Politik Hukum Pidana dalam Perlindungan Korban Kejahataan Ekonomi di Bidang Perbankan. Malang: Bayumedia Publishing.

Arif Setiawan. (2010). "Pembaharuan Pra Peradilan (Studi tentang Pemaknaan Hukum oleh Polisi dalam Penyidikan." Ringkasan Disertasi pada Program Doktor Ilmu Hukum, Universitas Diponegoro, Semarang. 
Barda Nawawi Arief. (2008). Bunga Rampai Kebijakan Hukum Pidana; Perkembangan Penyusunan Konsep KUHP Baru. Jakarta: Kencana Prenada Media Group.

(2008). Kebijakan Hukum Pidana; Perkembangan Penyusunan Konsep KUHP Baru. Jakarta: Kencana Prenada Media Group.

(2007). Masalah Penegakan Hukum dan Kebijakan Hukum Pidana dalam Penanggulangan Kejahatan. Jakarta: Kencana Prebada Media Group.

(2003). Kapita Selekta Hukum Pidana. Bandung: Citra Aditya Bakti.

. (1998). Beberapa Aspek Kebijakan Penegakan dan Pengembangan Hukum Pidana. Bandung: Citra Aditya Bakti.

Burhanuddin Lopa. (1996). Al Qur'an dan Hak Asasi Manusia. Yogyakarta: PT Dana Bhakti Prima Yasa.

C. De Rover. (2000). To Serve \& To Protect; Acuan Universal Penegakan HAM. Jakarta: PT. RajaGrafindo Persada.

Eddy O.S Hiariej. (2010). “Asas Legalitas Dalam Hukum Acara Pidana.” Disampaikan dalam Seminar Problem Dan Prospek RUU Hukum Acara Pidana Tim Pokja Nasional yang diselenggarakan Fakultas Hukum Universitas Gadjah Mada, Yogyakarta, Kamis 18 Maret 2010.

Haji N.A. Noor Muhammad. "Proses Hukum Bagi Orang yang Didakwa Melakukan Kejahatan, dalam Ifdhal Kasim (ed). (2001). Hak Sipil dan Politik; Esai-Esai Pilihan. Jakarta: Lembaga Studi dan Advokasi Masyarakat (ELSAM).

International Covenant on Civil and Political Rights, Adopted and opened for signature, ratification and accession by General Assembly resolution 2200A (XXI) of 16 December 1966

Miriam Budiardjo. (2008). Dasar-dasar Ilmu Politik. Jakarta: Penerbit Gramedia Pustaka Utama.

Markus Dirk Dubber. Criminal Law. (1999). "Reforming American Penal Law." Journal of Criminal Law and Criminology. Northwestern University School of Law. Diakses melalui http://www.westlaw.com pada tanggal 25 April 2011.

Moeljatno. (2008). Asas Asas Hukum Pidana. Jakarta: Penerbit Rineka Cipta.

Mokhammad Najih. (2008). Politik Hukum Pidana Pasca Reformasi. Malang: In-TRANS Publishing.

Muhadar, dkk. (2009). Perlindungan Saksi dan Korban dalam Sistem Peradilan Pidana. Surabaya: CV. Putra Media Nusantara.

Muladi (Editor). (2007). Hak Asasi Manusia; Hakekat, Konsep dan Implikasinya dalam Perspektif Hukum dan Masyarakat. Bandung: PT. Refika Aditama. dan Barda Nawawi. (2007). Bunga Rampai Hukum Pidana. Bandung: Alumni.

Restu Cipto Handoyo. (2003). Hukum Tata Negara, Kewarganegaraan, dan Hak Asasi manusia. Yogyakarta: Universitas Atma Jaya.

Rhona K.M Smith, dkk. (2008). Hukum Hak Asasi Manusia. Yogyakarta: Pusat Studi Hak Asasi Manusia (PUSHAM) Universitas Islam Indonesia.

Romli Atmasasmita. (2010). “Analisis kritis atas RUU HAP 2009.” Disampaikan dalam Seminar Problem Dan Prospek RUU Hukum Acara Pidana Tim Pokja Nasional yang 
Unisia, Vol. XXXVI, No.81 Juli 2014

diselenggarakan Fakultas Hukum Universitas Gadjah Mada, Yogyakarta, Kamis 18 Maret 2010.

Rusli Muhammad. (2007). Hukum Acara Pidana Kontemporer. Bandung: PT Citra Aditya Bakti.

Teguh Prasetyo. (2010). Kriminalisasi dalam Hukum Pidana. Bandung: Penerbit Nusa Media.

Undang-Undang Republik Indonesia Nomor 39 tahun 1999 tentang Hak Asasi Manusia.

Universal Declaration of Human Rights, Adopted by the United Nations (UN) of 10 Desember 1948.

Yesmil Anwar dan Adang. (2008). Pembaruan Hukum Pidana; Reformasi Pidana. Jakarta: PT Gramedia Widia Sarana Indonesia. 